\title{
Wynagrodzenia profesorów z Polski na Uniwersytecie Bolońskim w drugiej połowie XV wieku
}

Zarys treści: Artykuł jest poświęcony omówieniu wynagrodzeń profesorów pochodzących z Polski wykładających na Uniwersytecie Bolońskim w drugiej połowie XV w. Oparty jest na analizie zachowanych w Archiwum Państwowym w Bolonii wykazów wynagrodzeń wykładowców bolońskiej wszechnicy (od 1470 r.) oraz zachowanych w tymże archiwum wykazów kar finansowych nakładanych na tych wykładowców, którzy zaniedbywali odbywanie zajęć.

Content outline: The paper is devoted to the salaries of professors from Poland lecturing at the University of Bologna in the second half of the $15^{\text {th }}$ century. It is based on the analysis of the registers of salaries of professors of the University of Bologna preserved in the State Archive of Bologna (from 1470) and the lists housed in the same archive of financial penalties imposed on those lecturers, who did not held classes regularly.

Słowa kluczowe: Uniwersytet Boloński, polscy astronomowie XV w., wynagrodzenie profesorów

Keywords: University of Bologna, Polish astronomers of the 15th century, salaries of professors

W średniowiecznych uniwersytetach europejskich istniały różne modele wynagradzania profesorów. Należały do nich m.in.: system beneficjalny, prywatne fundacje katedr uniwersyteckich, wynagradzanie ze skarbca monarszego i wreszcie z kasy miejskiej ${ }^{1}$. W Bolonii profesorowie otrzymywali wynagrodzenie od komuny miejskiej za pośrednictwem jej wyspecjalizowanej agendy zwanej Gabella Grossa ${ }^{2}$. W Archiwum Państwowym w Bolonii (Archivio di Stato) znajdują się listy wynagrodzeń wykładowców bolońskiej wszechnicy poczynając od $1465 \mathrm{r}^{3}$ Ich nazwa (Quartironi degli stipendi) dowodzi, że honoraria za zajęcia były wypłacane kwartalnie, czyli

${ }^{1}$ A History of the University in Europe, t. I: Universities in the Middle Ages, red. H. de Ridder-Symoens, Cambridge 1992, s. 151-154. Za lekturę tekstu przed drukiem i poczynione uwagi dziękuję prof. Krzysztofowi Ożogowi.

2 M. C a r b o n i, La Gabella Grossa di Bologna. La formazione di una grande azienda fiscale, Il Carrobbio 16, 1990, s. 114-122.

3 Archivio di Stato di Bologna (dalej: ASB), Riformatori dello Studio, t. 33 i następne (Quartironi degli stipendi). Z początkowych lat (1465-1469) mamy tylko wykazy roczne lub półroczne, właściwe zestawienia kwartalne zaczynają się od 1470 r. Zwróciła na to uwagę A. D e Coster, Foreign and Citizen Teachers at Bologna University in the 15th and 16th Centuries. Statutes, Statistics and Student Teachers, Annali di storia delle università italiane 12, 2008, s. 329 n. 
cztery razy w roku. W interesującym nas tutaj okresie wynagrodzenia wypłacano zazwyczaj w kwietniu, lipcu, październiku i grudniu. Czasami zdarzało się, że ostatnią ratę wypłacano dopiero w styczniu z powodu natłoku różnego rodzaju prac administracyjnych ${ }^{4}$. Każda taka „płachta” kwartalnego uposażenia obejmuje nazwiska wszystkich wykładowców, którzy mieli zajęcia w danym roku akademickim, poczynając od uniwersytetów prawniczych (citramontanów i ultramontanów), poprzez uniwersytet medyków i artystów, a kończąc na osobach pełniących różne uniwersyteckie godności i funkcje. Roczna gaża była wypłacana w czterech ratach, ale nie były one równe. Widać wyraźnie, że pierwsze trzy raty były zazwyczaj skromniejsze, a dopiero czwarta uzupełniała roczne wynagrodzenie i czasami sięgała nawet jego połowy. Było to spowodowane kondycją finansową komuny bolońskiej, która wysokość wynagrodzenia dla poszczególnych grup wykładowców ustalała w swoich statutach ${ }^{5}$. Obok każdego nazwiska umieszczono kwotę rocznego uposażenia, a także wysokość danej raty. W nagłówku skryba dokładnie podawał, ile procent rocznego wynagrodzenia wynosiła konkretna rata. Dopełnieniem każdego dokumentu było zsumowanie wszystkich kwot oraz zatwierdzenie ich do wypłaty przez osoby do tego upoważnione. Wynagrodzenia wykładowców bolońskiego uniwersytetu były pomniejszane o kary za nieprzeprowadzanie zajęć. W bolońskim archiwum zachowały się także od 1465 r. tzw. appunctationes, czyli wykazy profesorów, którzy w konkretne dni nie odbyli zajęć i zostali ukarani tzw. punktami, czyli karą finansową ${ }^{6}$. Podobnie jak wykazy pensji, listy te sporządzano zazwyczaj co kwartał. Wysokość kary za zaniedbywanie obowiązków dydaktycznych zaznaczano także na listach płac. Tę niewdzięczną uniwersytecką powinność wykonywał urzędnik zwany w źródłach punctator.

W wymienionych źródłach występują w drugiej połowie XV w. (a dokładniej od 1470 r. do końca stulecia) nazwiska czterech Polaków, którzy prowadzili zajęcia na Uniwersytecie Bolońskim i pobierali z tego tytułu wynagrodzenie ${ }^{7}$. Byli to: Jakub z Zalesia, Jan de Bossis, Jerzy Koternak ze Lwowa i Mikołaj Wodka z Kwidzynia. Jak widać, są to znakomite postacie polskiej astronomii (i astrologii) późnośredniowiecznej. Wszyscy wykładali na uniwersytecie artystów i medyków. W przypadku

4 Tak zdarzyło się pod koniec 1475 r., kiedy to planowaną na 23 grudnia ratę wypłacono dopiero 8 I 1476 r. Skryba na odwrocie karty zanotował: Quarta et ultima distributio dominorum et doctorum anni 1475 que fuit expedita hoc die octavo Januarii 1476, quovis expediri debuisset die XXIII Decembris 1475, quod fieri non potuit ob multa alia negotia, que huic taxe ne expediri posset fuerunt impedimento etc. (ASB, Riformatori dello Studio, t. 33, nr 9 [1475], k. 30).

5 ASB, Comune Governo, Statuti, t. 51, k. 598r-600v. G. M o r e 11 i, De Studio scolarium civitatis Bononie manutenendo. Gli statuti del Comune (1335-1454) per la tutela dello Studio e delle Università degli scolari, Archiginnasio 76, 1981, s. 140-142; Gli Statuti del Comune di Bologna degli anni 1352, 1357; 1376, 1389 (libri I-III), wyd. V. Braidi, t. II, Bologna 2002, s. 1109 n. Zob. też A. S o r b e 11 i, Gli stipendi dei Professori dell'Università di Bologna nel secolo XIV, L'Archiginnasio 7, 1912, s. 313-319.

6 ASB, Riformatori dello Studio, t. 50 (Appuntazioni dei lettori).

7 Za Polaków uważam te osoby, które w aktach uniwersyteckich określały się mianem Polonus, niezależnie od faktu, że czasami niejasno wygląda sprawa ich pochodzenia. W szczególności odnosi się to do Jana de Bossis. 
Jakuba z Zalesia i Mikołaja Wodki dysponujemy tylko skromnymi informacjami o ich pensjach, co wynika z faktu niezachowania się pełnych list wypłat z lat, w których pracowali oni w murach bolońskiego uniwersytetu. W odniesieniu natomiast do Jana de Bossis i Jerzego Koternaka posiadamy zarówno kwartalne zestawienia ich poborów, jak i - niestety - wykazy opuszczonych przez nich zajęć, co zwłaszcza w przypadku lwowskiego astronoma zdarzało się dosyć często. Warto też dodać, że analizowane poniżej wykazy wynagrodzeń uszły do tej pory uwadze polskich badaczy, którzy koncentrowali się raczej na źródłach dotyczących uzyskania przez Polaków stopni uniwersyteckich na Uniwersytecie Bolońskim.

Jan de Bossis to dosyć tajemnicza postać. Pomimo niepolsko brzmiącego miejsca pochodzenia uważał się za Polaka i za takiego podawał w aktach bolońskiego uniwersytetu (Polanus, Polonus) ${ }^{8}$. Historycy przypuszczają, że albo urodził się w Polsce, ale spędził tutaj dłuższy czas ${ }^{9}$. Zapewne przynależał do mediolańskiej rodziny Bossi, której kilku przedstawicieli przebywało w XV w. w naszym kraju. W 1435 r. biskup poznański Stanisław Ciołek udzielił Franciszkowi de Bossis, zapewne krewnemu Jana, prowizji na scholasterię poznańską, której jednak - wobec sprzeciwu kapituły - zainteresowany nie objął. Otrzymał w zamian beneficja w kapitule trydenckiej. Franciszek jako doktor obojga praw był później adwokatem Zakonu Krzyżackiego na soborze w Bazylei ${ }^{10}$. Inny członek tej rodziny, Izydor, towarzyszył Antoniemu Zeno w misji do Polski w 1422 r., mającej na celu rozsądzenie sporu polsko-krzyżackiego. Wymienieni Włosi przebywali także na dworze księcia mazowieckiego Aleksandra, który w latach 1423-1444 był biskupem Trydentu ${ }^{11}$.

Jan de Bossis pojawia się w rotułach Uniwersytetu Bolońskiego w roku akademickim 1471/72 jako wykładowca astronomii. Tę dziedzinę wykładał także w latach 1472/73 i 1474/75 ${ }^{12}$. W zachowanych listach płac nazwisko Jana (określanego jako Johannes Polonus) występuje od 1472 r. Wynagrodzenie za całoroczny kurs z astronomii zostało ustalone dla naszego wykładowcy na kwotę 50 libr bolońskich. Taka wysokość wynagrodzenia za ten kurs pojawia się już w statutach komuny bolońskiej w 1389 r. i nie uległa zmianie przez następne stulecie ${ }^{13}$. Warto zauważyć, że w tym

8 ASB, Riformatori dello Studio, t. 33, nr 6 (1472), nr 7 (1473), nr 8 (1474), nr 9 (1475); I rotuli dei lettori, legisti e artisti dello Studio Bolognese dal 1384 al 1799, wyd. U. Dallari, t. I, Bologna 1888 .

9 A. B irke nmajer, Jan de Bossis, w: Polski słownik biograficzny, t. X (19621964), s. 443; tenże, Etudes d'histoire des sciences en Pologne, Wrocław 1972, s. 548; J. Dobrzycki, M. Markowski, T. Przypkowski, Historia astronomii w Polsce, t. I, Wrocław 1975, s. 101; P. W. K n o 11, „A Pearl of Powerful Learning”. The University of Cracow in the Fifteenth Century, Leiden-Boston 2016, s. 391.

10 P. D e m b iń s k i, Poznańska kapituła katedralna schyłku wieków średnich. Studium prozopograficzne 1428-1500, Poznań 2012, s. 383.

11 L. B ą k o w s ki, Książę mazowiecki Aleksander, biskup trydencki, Przegląd Historyczny 16,1913 , s. $147-148$.

12 I rotuli dei lettori, s. 87, 90, 96; F. B ò noli, D. P i 1 i a r v u, I lettori di astronomia presso lo Studio di Bologna dal XII al XX secolo, Bologna 2001, s. 113.

13 G. M o r e 11 i, De Studio scolarium, s. 140: qui legere debeat in astrologia cum salario quinquaginta librarum bononinorum pro quolibet anno et pro toto anno que salaria solvi debeant per comune Boninie et de avere ipsius comunis; Gli Statuti del Comune di Bologna, t. II, s. 1109 n. 
samym okresie pensja dla profesorów prawa wynosiła 100 libr bolońskich za jeden całoroczny kurs ${ }^{14}$. Niektórzy profesorowie prawa prowadzący po kilka kursów zarabiali rocznie nawet kilkaset libr. W 1472 r. Jan de Bossis otrzymał łącznie 54 libry, czyli nawet o kilka więcej, niż było to przewidziane. Poszczególne raty w 1472 r., jak i w latach następnych, przedstawia poniższa tabela. Jednostką monetarną była libra bolońska, która dzieliła się na 20 solidów.

\begin{tabular}{|l|c|c|c|c|}
\hline & $1472^{15}$ & $1473^{16}$ & $1474^{17}$ & $1475^{18}$ \\
\hline I rata & 15 & 7,10 & 5 & 6 \\
\hline II rata & 0 & 7 & 3,15 & 28 \\
\hline III rata & 10 & 7 & 8 & 0 \\
\hline IV rata & 29 & 15 & 11,10 & 0 \\
\hline Razem & 54 & 36,10 & 28,05 & 34 \\
\hline
\end{tabular}

Jak wynika z powyższej tabeli, roczne pobory Jana w latach 1473-1475 były już znacznie mniejsze aniżeli 50 libr, co wiązało się z sytuacją finansową miasta. Inni wykładowcy też nie otrzymali wówczas pełnego rocznego wynagrodzenia. Jan de Bossis nie otrzymał żadnego wynagrodzenia za drugą połowę 1475 r., co wynikało zapewne z faktu jego bardzo licznych absencji na wykładach. Zachowane wykazy tych nieobecności wskazują, że od kwietnia do czerwca $1475 \mathrm{r}$. Jan został ukarany 21 punktami, tzn. że przez 21 dokładnie wyliczonych dni nie prowadził zajęć, za co mu odjęto z pensji stosunkowo sporą kwotę 15 libr i 15 solidów $^{19}$. Jeśli dodamy do tego 9 punktów karnych za opuszczenie zajęć w miesiącach lipiec-sierpień, co zostało przeliczone na 6 libr i 15 solidów, to w rzeczywistości Janowi nie należało się żadne wynagrodzenie ${ }^{20}$. Ciekawi natomiast pobranie 26 VII 1475 r. stosunkowo dużej kwoty 28 libr, czyli ponad połowy rocznej gaży ${ }^{21}$.

Podczas pobytu w Bolonii Jan de Bossis napisał prognostyk na temat komety, która pojawiła się na początku stycznia 1472 r. (Tractatus de cometa, qui apparuit anno Domini 1472 currente in diebus Ianuarii, magistri Johannis de Bossis Poloni) ${ }^{22}$. Dziełko swoje zadedykował Mikołajowi Stolzowi, biskupowi elektowi Wielkiego

${ }^{14}$ G. M o r e 11 i, De Studio scolarium, s. 140.

15 ASB, Riformatori dello Studio, t. 33, nr 6 (1472).

16 Tamże, nr 7 (1473).

17 Tamże, nr 8 (1474).

18 Tamże, nr 9 (1475).

19 Tamże, t. 50, k. 32v.

20 Tamże, k. $35 \mathrm{v}$.

${ }^{21} \mathrm{Z}$ powyższych wyliczeń wynika, że kara za jeden dzień absencji na zajęciach wynosiła 15 solidów, ale nie było tak zawsze.

${ }_{22}$ München, Bayerische Staatsbibliothek, ms. 23883, k. 1r-7v. Zob. L. Th orndike, A History of Magic and Experimental Science, t. IV, New York 1934, s. 422-424; M. M a rk o w s k i, I legami fra la scuola cracoviana di astronomia e l'Università di Bologna nel secolo XV, w: Commentationes historicae, Warszawa-Kraków 1988, s. 119; t e n ż e, Astronomia et astrologia Cracoviensia [!] ante annum 1550, Firenze 1990, s. 46; t e n ż e, Repertorium bio-bibliographicum astronomorum Cracoviensium medii aevi, Studia Mediewistyczne 28, 1992, s. 107. 
Waradynu w ówczesnym Królestwie Węgier ${ }^{23}$. Warto podkreślić, że w Archiwum Państwowym w Mediolanie jest przechowywany odpis tego traktatu ${ }^{24}$. Dziełkiem tym Jan de Bossis włączył się do międzynarodowej debaty astronomów europejskich o wspomnianej komecie, w której uczestniczyli Jan Regiomontanus, Paweł Toscanelli, Mikołaj Hartmann, Jan z Głogowa, Marcin Bylica z Olkusza, Mikołaj z Ciężkowic i Walenty z Zatora ${ }^{25}$. Poza wymienionymi przekazami źródłowymi nie dysponujemy obecnie innymi źródłami mogącymi dodatkowo oświetlić żywot tego astronoma.

Jerzy Koternak z Drohobycza, piszący się także ze Lwowa lub z Rusi, to kolejny Polak, którego spotykamy na bolońskiej liście płac. Podobnie jak Jan de Bossis, Jerzy ze Lwowa był astronomem, a o jego życiu zachowało się całkiem sporo przekazów źródłowych. Zanim przybył do Bolonii, studiował w Krakowie, gdzie w 1470 uzyskał stopień bakałarza, a w 1473 r. - magistra ${ }^{26}$. Zdaniem niektórych badaczy po uzyskaniu krakowskiego magisterium miał wyjechać na Węgry i wykładać w założonym przez króla Macieja Korwina Uniwersytecie Istropolitańskim w Pożoniu (dzisiejsza Bratysława $)^{27}$. Następnie wraz ze swoim uniwersyteckim kolegą Mikołajem Wodką z Kwidzynia udał się do Włoch, gdzie podjął studia z zakresu medycyny na uniwersytecie w Bolonii. W roku akademickim 1478/79 wykładał w Bolonii astronomię. Zajęcia $\mathrm{z}$ astronomii miał także w latach $1480 / 81$ oraz $1481 / 82^{28}$. W tym ostatnim roku wykładał także medycynę, ale tylko in diebus festis ${ }^{29}$. W 1481 r. został wybrany na rektora medyków i artystów bolońskiej wszechnicy ${ }^{30}$. Zgodnie z bolońską tradycją przed wybraniem go na rektora, zrezygnował 28 II 1481 r. z wykładów, a następnie, zapewne w marcu, objął urząd rektorski. Wykłady przybysza z dalekiej Rusi

${ }^{23}$ L. Th orndike, A History of Magic, t. IV, s. 422; A. K o złow s k a, Polskie prognostyki o komecie z 1472 roku. Analiza zawartości treściowej, Studia Mediewistyczne 29, 1992, s. 47.

24 Archivio di Stato di Milano, Archivio Ducale Visconteo Sforzesco-Potenze Sovrane, cart. 1569, fasc. 5-6 (Magister Johannes de Bossis Polonus in cometam). Zob. P. O. K r is te 1 1 e r, Iter Italicum. Accedunt alia itineraria. A Finding List of Uncatalogued or Incompletely Catalogued Humanistic Manuscripts of the Renaissance in Italian and Other Libraries, t. VI, Leiden-London 1992, s. 28; F. B òn o 1 i, D. P i 1 i a rv u, I lettori di astronomia, s. 114; M. A z z o 1 i n i, The Duke and the Stars. Astrology and Politics in Renaissance Milan, Harvard 2013, s. 115.

${ }^{25} \mathrm{~K}$. O ż ó g, The Role of Poland in the Intellectual Development of Europe in the Middle Ages, Kraków 2009, s. 148.

${ }^{26}$ Metryka Uniwersytetu Krakowskiego z lat 1400-1508, wyd. A. Gąsiowski, T. Jurek, I. Skierska, przy współpracy R. Grzesika, Kraków 2004, t. I, s. 333, nr 68h/239; Najstarsza księga promocji Wydziału Sztuk Uniwersytetu Krakowskiego z lat 1402-1541, wyd. A. Gąsiorowski, T. Jurek, I. Skierska, Warszawa 2011, s. 233 nr 70/77B, s. 235 nr 73/4M.

27 L. A. B irk e n m a j e r, Mikołaj Wodka z Kwidzynia zwany Abstemius lekarz i astronom polski XV stulecia, Roczniki Towarzystwa Naukowego w Toruniu 33, 1926, s. 148, przyp. 1.

28 I rotuli dei lettori, s. 107, 112, 115; F. B ò n o 1 i, D. P i 1 i a r v u, I lettori di astronomia, s. $115-117$.

29 A. S i m i 1 i, I lettori di medicina e chirurgia nello Studio di Bologna dal 1460 al 1500, Bologna 1941, s. 38.

${ }^{30} \mathrm{C}$. M a la g o la, I rettori nell'antico Studio e nella moderna università di Bologna, w: tenże, Monografie storiche sullo Studio Bolognese, Bologna 1888, s. 175; S. A. S ro k a, I rettori polacchi dell'universitas scholarium dello Studio bolognese nella seconda metà del XV secolo, Annali di storia delle università italiane 19, 2015, nr 2, s. 85. 
musiały się cieszyć powodzeniem, albowiem podczas zgromadzenia uniwersyteckiego 12 IV 1481 r. jednomyślnie postanowiono, że powinien on je kontynuować, pomimo złożonej rezygnacji. Wyznaczono mu także wynagrodzenie w wysokości 50 libr bolońskich ${ }^{31}$. Jerzy ze Lwowa był rektorem do wiosny 1482 r., kiedy to z nieznanych nam przyczyn zrzekł się tej godności ${ }^{32}$.

Lista płac bolońskiego uniwersytetu dowodzi, że Jerzy ze Lwowa w pierwszym roku swojego zatrudnienia nie wywiązywał się należycie ze swoich dydaktycznych obowiązków, ponieważ prawie w ogóle nie prowadził zajęć i z tego powodu nie wypłacono mu pensji. Skryba na każdej „płachcie” przygotowanej do kwartalnej wypłaty odnotował przy nazwisku Jerzego: non legit ${ }^{33}$. Natomiast wspomniany już wcześniej uniwersytecki urzędnik zwany punctator, który odnotowywał nieobecności wykładowców na zajęciach, zapisał w zestawieniu obejmującym okres od czerwca do sierpnia 1479 r.: M. Georgius de Rusia non est taxatus. Habet punctationes quindecim. Non legit. Non debet habere salarium ${ }^{34}$. Wspomniane w tym zapisie 15 punktów karnych oznacza, że Jerzy nie odbył 15 zajęć w ciągu tych trzech miesięcy, a kara finansowa za to przewinienie prawdopodobnie przewyższała przewidziane za ten okres wynagrodzenie, stąd informacja, że owo wynagrodzenie mu się nie należy. Trudno określić przyczynę tej nadmiernej absencji Jerzego na wykładach. Zupełnie inaczej wyglądała sytuacja w roku 1481 i 1482. Jego ówczesne wynagrodzenie przedstawia poniższa tabela. Podobnie jak w przypadku Jana de Bossis, roczne uposażenie Jerzego ze Lwowa było określone na poziomie 50 libr.

\begin{tabular}{|l|c|c|}
\hline & $1481^{35}$ & $1482^{36}$ \\
\hline I rata & 7 & 5,15 \\
\hline II rata & 5 & 0 \\
\hline III rata & 2,5 & 0 \\
\hline IV rata & 22,10 & 22,10 \\
\hline Razem & 36,15 & 28,5 \\
\hline
\end{tabular}

Tabela powyższa wymaga kilku uwag. Po pierwsze, z racji pełnienia funkcji rektora uniwersytetu medyków i artystów, który to urząd objął na wiosnę $1481 \mathrm{r}$., Jerzemu przynależało dodatkowe wynagrodzenie w wysokości 100 libr i, jak dowodzi lista płac, takowe otrzymał 13 VIII 1481 r. ${ }^{37}$ Po drugie, jak wspomniałem wcześniej,

${ }^{31}$ C. P i a n a, Nuovi documenti sull'Università di Bologna e sul Collegio di Spagna, Bolonia 1976 (Studia Albornotiana, XXVI), s. 56.

32 Diario bolognese di Mํ Gaspare Codibó dal 1471 al 1504, wyd. A. Macchiavelli, Bologna 1915 (Biblioteca de L'Archiginnasio, ser. II, nr 9), s. 46: alius de Russia [chodzi o Jerzego] cessavit a rectoratu; S. A. S rok a, Polacy w Bolonii u schyłku średniowiecza w świetle diariusza Gaspare Codibò z lat 1471-1508, w: Memoria viva. Studia historyczne poświęcone pamięci Izabeli Skierskiej (1967-2014), Warszawa-Poznań 2015, s. 671-672.

${ }^{33}$ ASB, Riformatori dello Studio, t. 33, nr 13 (1479).

34 Tamże, t. 50, k. 63-64.

35 Tamże, t. 33, nr 15 (1481).

36 Tamże, nr 16 (1482).

37 Tamże, nr 15 (1481). 
Jerzy otrzymał specjalne pozwolenie na prowadzenie zajęć pomimo pełnienia funkcji rektorskiej. Niestety objęcie tego urzędu spowodowało zaniedbywanie obowiązków wykładowcy, co wyraźnie widać w listach punctationes, wedle których od kwietnia do czerwca 1481 r. Jerzy 7 razy nie odbył zajęć, za co został ukarany kwotą 5 libr i 5 solidów ${ }^{38}$. Zostały mu one odjęte od wynagrodzenia w jesieni (III rata za 1481), kiedy otrzymał tylko 2 libry i 5 solidów zamiast 7 libr i 10 solidów $^{39}$. W późniejszych miesiącach roku 1481 Jerzy ze Lwowa opuszczał już tylko nieliczne zajęcia. Od października do grudnia tego roku nie odbył zajęć tylko w jeden dzień (2 grudnia $)^{40}$ i ściągnięto mu z wynagrodzenia 15 solidów w pierwszej racie w $1482 \mathrm{r}$. Wreszcie w pierwszym kwartale 1482 r. lwowski astronom zaniedbał 4 zajęcia, co skutkowało karą 3 libr, a w okresie od lipca do sierpnia nie odbył zajęć aż 13 razy, za co ukarano go kwotą 9 libr i 15 solidów $^{41}$, co w konsekwencji oznaczało pozbawienie wynagrodzenia praktycznie przez pół roku (II i III rata z tego roku).

Pobyt w Bolonii Jerzy ze Lwowa uwieńczył stopniem doktora medycyny. Nie znamy daty jego uzyskania, ale wydaje się, że stało się to w 1482 r., zaraz po ustąpieniu z rektorskiego krzesła. W każdym razie Jerzy już w tym roku występuje z tytułem doktora medycyny ${ }^{42}$. Podczas pobytu w Bolonii Jerzy opracował dwa prognostyki astrologiczne: Iudicium anni 1478 oraz Iudicium anni $1483^{43}$. W tym drugim dziełku tytułuje się już doktorem medycyny. Jest ono ważne przede wszystkim z uwagi na zawarte w nim wiadomości z zakresu geografii Rusi ${ }^{44}$. Jerzy ze Lwowa jest także autorem pracy Collecta super iudicium de eclipsibus ${ }^{45}$. Jeden z odpisów tego ostatniego dzieła znajduje się w zbiorach Archiwum Państwowego w Mediolanie, na co zwrócili uwagę włoscy badacze ${ }^{46}$.

Po wyjeździe z Bolonii i krótkim pobycie w Ferrarze Jerzy ze Lwowa powrócił do Krakowa, gdzie inkorporował się do Wydziału Medycznego Uniwersytetu

38 Tamże, t. 50, k. $72 \mathrm{v}$.

39 Tamże, t. 33, nr 15 (1481).

40 Tamże, t. 50, k. 74v.

${ }^{41}$ Tamże, k. 76v., 78v.

${ }^{42}$ Monument Poloniae Vaticana, t. X (Akta Kamery Apostolskiej, t. IV: Annaty z Królestwa Polskiego w XV wieku [1421-1503]), wyd. M. D. Kowalski, Kraków 2002, nr 840. Jego imienia nie ma w zachowanym od 1480 r. do naszych czasów wykazie wypromowanych w Bolonii doktorów medycyny. Zob. G. B r o n z i n o, Notitia doctorum sive catalogus doctorum qui in collegis philosophiae et medicinae Bononiae laureati fuerunt ab anno 1480 usque ad annum 1800, Milano 1962. Taką datę doktoratu Jerzego przyjmuje także J. I s a j e w i c z, Jerzy z Drohobycza we Włoszech i w Krakowie, Małopolskie Studia Historyczne 6, 1963, nr 3-4, s. 61, podpierając się korespondencyjną opinią uczonego włoskiego, prof. Giovanniego Cencettiego.

${ }^{43}$ H. P e s s in a L o n g o, Georgius de Russia, rettore a Bologna nel XV secolo, Bologna 1988, s. 34, 59-62; M. M a r k o w s k i, Astronomia, s. 33-34; t e n ż e, Repertorium, s. 91-92.

44 J. I s a j e w i c z, Jerzy z Drohobycza, s. 62-63.

${ }^{45}$ G. R o s iń s k a, Scientific Writings and Astronomical Tables in Cracow a Census of Manuscript Sources (XIVth-XVIth Centuries), Wrocław 1984 (Studia Copiernicana XXII), s. 30, 32; M. M a r k o w s k i, I legami, s. 120; t e n ż e, Repertorium, s. 93.

${ }^{46}$ Archivio di Stato di Milano, Archivio Ducale Visconteo Sforzesco-Potenze Sovrane, cart. 1569, fasc. 2-4; H. P e s s i na Longo, Georgius de Russia, s. 61-82; F. B ò n oli, D. P i l i a rv u, I lettori di astronomia, s. 116-117. 
Krakowskiego. W 1488 r. otrzymał dożywotnio działkę w pobliżu Bursy Węgierskiej, na której postawił własny dom. Dzierżył dochody z kilku beneficjów, był scholastykiem kruszwickim i plebanem w Zimnej Wodzie koło Lwowa, nade wszystko zaś profesorem uniwersytetu i medykiem na dworze Kazimierza Jagiellończyka. Utrzymywał kontakty z rodzinnymi stronami - bywał we Lwowie i Drohobyczu. Umarł w Krakowie 4 II 1494 r. ${ }^{47}$

Informacje o pensjach pozostałych dwóch polskich wykładowców Uniwersytetu Bolońskiego w interesującym nas okresie są już znacznie skromniejsze. Jakub z Zalesia, jak wynika z uniwersyteckich rotułów, wykładał w roku akademickim $1469 / 70$ matematykę ${ }^{48}$. Nie były to zajęcia dobrze płatne, gdyż zachowana lista płac z 20 VI 1471 r. świadczy, że Jakub otrzymał wynagrodzenie w wysokości 15 libr, $\mathrm{i}$ to $\mathrm{z}$ dosyć dużym opóźnieniem, uniwersytecki skryba zapisał bowiem, że kwota ta była pro anno preterito ${ }^{49}$. Jakub, zanim udał się na studia do Bolonii, pobierał od 1454 r. nauki na Uniwersytecie Krakowskim, gdzie dwa lata później został bakałarzem, a w 1462 r. - magistrem ${ }^{50}$. Po krótkim epizodzie wykładowcy krakowskiej wszechnicy (w zastępstwie zawieszonego Szymona ze Śremu) udał się do Bolonii. Oprócz podjęcia wykładów z matematyki, Jakub wziął też udział w 1471 r. w dyspucie z Bartłomiejem z Walencji na temat tzw. równania czasu, czyli różnicy pomiędzy czasem astronomicznym a czasem średnim. Jakub swoje poglądy w tej kwestii wyłożył potem w pracy: Rationes magistri Jacobi Zalesse Poloni contra positiones falsas magistri Bartholomei de Valencia de dierum aequationibus et earum causis ${ }^{51}$. Pobyt w Bolonii Jakub uwieńczył zapewne laurem doktorskim z medycyny. Nie wiemy, kiedy to dokładnie nastąiło, zachowany wykaz wypromowanych w Bolonii doktorów medycyny zaczyna się bowiem od $1480 \mathrm{r}^{52}$ Po powrocie z Włoch Jakub został lekarzem nadwornym króla czeskiego Władysława Jagiellończyka, a potem samego króla Kazimierza, któremu służył medycznymi poradami aż do jego śmierci ${ }^{53}$. Dzięki królewskiej protekcji wszedł w posiadanie kilku beneficjów kościelnych. Był plebanem wiślickim, kanonikiem krakowskim ${ }^{54}$, gnieźnieńskim ${ }^{55}$,

47 S. A. S r o k a, Polacy w Bolonii, s. 672-673.

48 I rotuli dei lettori, s. 81; F. B ò n o li, D. P i li a rv u, I lettori di astronomia, s. 110.

49 ASB, Riformatori dello Studio, t. 33, nr 5 (1471).

50 A. B irke n ma je r, Jakub z Zalesia, w: Polski słownik biograficzny, t. X (19621964), s. 370.

${ }^{51}$ L. A. B i r k e n m a j e r, De diebus naturalibus earumque aequatione. Ouvrage de Barthélemy Berp de Valentia, astronome du XV-me siècle, Bulletin International de l'Académie des Sciences de Cracovie, Classe des sciences mathématiques et naturelles, seria A: Sciences mathématiques, 1912 (druk: 1913), s. 339-379; L. T h or n d i k e, A History of Magic, t. IV, s. 444; G. R o s iń s k a, Scientific Writings, s. 145; M. M ark ow s k i, I legami, s. 118-119; t e n ż e, Astronomia, s. 44; te n że, Repertorium, s. 106.

52 G. B r o n z in o, Notitia doctorum.

${ }^{53}$ M. S t a r z y ń s k i, Zgon i pogrzeb Kazimierza Jagiellończyka (1492), w: Narodziny Rzeczypospolitej. Studia z dziejów średniowiecza i czasów wczesnonowożytnych, t. II, Kraków 2012, s. 929.

54 J. L a c h s, Lekarze krakowskiej kapituły katedralnej, Kraków 1905, s. 17-18.

55 H. R y b u s, Królewicz kardynał Fryderyk Jagiellończyk jako biskup krakowski i arcybiskup gnieźnieński, Warszawa 1935, s. 61. 
włocławskim $^{56}$, płockim i prepozytem kolegiaty tarnowskiej. Po śmierci Kazimierza Jagiellończyka został medykiem jego syna, kardynała Fryderyka. Zmarł przed 27 VI 1496 r. $^{57}$

W uniwersyteckich rotułach Uniwersytetu Bolońskiego w roku akademickim 1479/80 jako wykładowca astronomii figuruje Nicolaus de Insula Marie Polanus ${ }^{58}$. To Mikołaj Wodka z Kwidzynia (Marienwerder) zwany ironicznie Abstemius, później znakomitej sławy astronom i lekarz ${ }^{59}$. Z 1480 r. nie zachowała się pełna lista płac bolońskiej profesury (podzielona na kwartały), ale szczęśliwie dotrwał pewien wyciąg obejmujący lata 1478-1487, w którym pod datą 27 VII 1480 r. widnieje nota o wypłaceniu Mikołajowi Wodce za odbyte wykłady gaży w wysokości 50 libr $^{60}$. Co ciekawe, autor znakomitej biografii Wodki, Ludwik Antoni Birkenmajer, nie znając co prawda tej list płac, doszukał się tej samej informacji o wynagrodzeniu Wodki za wykłady w aktach komuny bolońskiej ${ }^{61}$.

Mikołaj, zanim przybył do Bolonii, zapisał się na Wydział Sztuk Uniwersytetu Krakowskiego w 1462 r. ${ }^{62}$ Edukacji w Krakowie nie sfinalizował uzyskaniem stopnia naukowego. Niektórzy przypuszczają, że uzyskał go na krótko działającej akademii w Pożoniu ${ }^{63}$. Około 1475 r. przybył na dalsze studia do Bolonii ${ }^{64}$. Tutaj, zanim rozpoczął wykłady, opracował tablice astronomiczne oraz prognostyk na 1477 r., który dedykował Jakubowi z Sienna arcybiskupowi gnieźnieńskiemu. Podczas pobytu Mikołaja w Bolonii, już po jego promocji na doktora medycyny, powstały jeszcze Canones tabularum resolutarum ad meridianum Bononie ${ }^{65}$. Nie znamy dokładnej daty uzyskania stopnia doktorskiego, ale zapewne stało się to w 1480 r. Potwierdza to kolofon jednego z rękopisów Wodki znajdujących się w Bibliotece Królewskiej w Sztokholmie (Kungliga biblioteket), w którym czytamy: me iam annis multis latitantem Nicolaus de Insula Marie Sarmate doctor cathedralis astrorum Bononie emendatum in lucem reduxit anno Christi MCCCCLXXX ${ }^{66}$. Po opuszczeniu Bolonii i krótkim pobycie w Rzymie i Urbino Mikołaj w 1482 r. wrócił do Polski. Osiadł w Poznaniu, gdzie zyskał szybko sławę świetnego medyka i astrologa. Opracował tam prognostyk na rok 1485. Około 1488 r. przeniósł się do Włocławka, gdzie został

56 A. Gą s i orow ski, Kanonicy włocławscy w najstarszej metryce kapitulnej (14351500), w: Duchowieństwo kapitulne w Polsce średniowiecznej i wczesnonowożytnej. Studia nad pochodzeniem i funcjonowaniem elity kościelnej, Toruń 2000, s. 35, 37-38.

57 A. B ir k e n m a j e r, Jakub z Zalesia, s. 370-371.

58 I rotuli dei lettori, s. 110; F. B ò n o li, D. P i li a rv u, I lettori di astronomia, s. 117.

59 L. A. B irken m a j e r, Mikołaj Wodka.

${ }^{60}$ ASB, Riformatori dello Studio, t. 33, nr 32: M. Nicolaus Polonus rotulatus ad astronomiam obtinuit sibi solvi salarium pro tempore elapso ad rationem librarum quinquaginta.

${ }^{61}$ L. A. B i r k e n m a j e r, Mikołaj Wodka, s. 55. Oryginalny zapis w: ASB, Comune Governo, t. 388 (Riformatori dello Stato di Libertà, Libri partitorum, nr 10, k. 28v).

${ }_{62}$ Metryka Uniwersytetu Krakowskiego, s. $298 \mathrm{nr} 62 \mathrm{~h} / 126$.

${ }_{63}$ M. M a r k o w s k i, Okresy rozwoju astronomii w Polsce w epoce przedkopernikańskiej, Studia Warmińskie 9, 1972, s. 371; P. W. K n o 11, „A Pearl of Powerful Learning”, s. 391.

${ }^{64}$ L. A. B irke n m aj e r, Mikołaj Wodka, s. 42.

65 Tamże, s. 236-240; G. R o s i ń s k a, Scientific Writings, s. 48, 354-355; M. M a r k o w s k i, Astronomia, s. 158-160.

${ }^{66}$ P. O. Kriste 11 e r, Iter Italicum, t. V, London-Leiden 1990, s. 13; F. B ò n o li, D. Pil i a rv u, I lettori di astronomia, s. 117. 
lekarzem biskupa Piotra z Bnina oraz kanonikiem w tamtejszej kapitule. We Włocławku powstały dwa prognostyki dotyczące przyszłości państwa tureckiego ${ }^{67}$. Tutaj też spotkał młodziutkiego Mikołaja Kopernika, który wybierał się na studia do Krakowa. Wpływ, jaki wywarł Wodka na Kopernika, pięknie ujął niegdyś L. A. Birkenmajer: „modelował niejako młodzieńczą jego duszę - - sam nauce astronomii gorąco oddany, powabami pięknej sztuki gwiaździarskiej przyszłego arcymistrza do niej przyciągnął i trwale pozyskał"68. Podczas pobytu we Włocławku Mikołaj Wodka sporządził zegar słoneczny na południowej ścianie tamtejszej katedry. Umarł przed 7 I 1495 r. ${ }^{69}$

Pora na krótkie podsumowanie niniejszych rozważań. Listy płac profesorów Uniwersytetu Bolońskiego w XV w., jak również listy kar nakładanych na tych, którzy opuszczali wykłady, to niewątpliwie źródła wyjątkowe, pozwalające wniknąć w życie codzienne uniwersytetu oraz w jego organizację zajęć. Z analizowanego okresu (czyli od 1470 r. do końca stulecia) wśród profesorów tej najstarszej europejskiej wszechnicy byli także Polacy, znakomici później astronomowie, którzy wszakże udali się do Bolonii po laury doktorskie z medycyny, które zapewniały, zarówno wówczas, jak i dzisiaj, lepszy byt materialny. Dzięki tym źródłom wiemy, że nie zawsze pilnie wykonywali swoje profesorskie obowiązki, zaniedbując zajęcia. Niemniej każdy z tych astronomów (Jan de Bossis, Jerzy Koternak ze Lwowa, Jakub z Zalesia i Mikołaj Wodka z Kwidzynia) pozostawił po sobie różnego rodzaju dzieła astronomiczne (astrologiczne). Mikołaj Wodka swoją wiedzą natchnął zaś młodziutkiego Mikołaja Kopernika do zajęcia się astronomią. Nie ulega też wątpliwości, że wszyscy zaliczani byli do elity intelektualnej w Polsce w ostatnich trzech dekadach XV w.

\section{BIBLIOGRAFIA}

A History of the University in Europe, t. I: Universities in the Middle Ages, red. H. de Ridder-Symoens, Cambridge 1992.

Azzolini M., The Duke and the Stars. Astrology and Politics in Renaissance Milan, Harvard 2013.

Bąkowski L., Książę mazowiecki Aleksander, biskup trydencki, Przegląd Historyczny 16, 1913.

Birkenmajer A., Etudes d'histoire des sciences en Pologne, Wrocław 1972.

Birkenmajer A., Jakub z Zalesia, w: Polski słownik biograficzny, t. X (1962-1964).

Birkenmajer A., Jan de Bossis, w: Polski słownik biograficzny, t. X (1962-1964).

Birkenmajer L. A., De diebus naturalibus earumque aequatione. Ouvrage de Barthélemy Berp de Valentia, astronome du XV-me siècle, Bulletin International de l'Académie des Sciences de Cracovie, Classe des sciences mathématiques et naturelles, seria A: Sciences mathématiques, 1912 (druk: 1913).

Birkenmajer L. A., Mikołaj Wodka z Kwidzynia zwany Abstemius lekarz i astronom polski XV stulecia, Roczniki Towarzystwa Naukowego w Toruniu 33, 1926.

Bònoli F., Piliarvu D., I lettori di astronomia presso lo Studio di Bologna dal XII al XX secolo, Bologna 2001.

Bronzino G., Notitia doctorum sive catalogus doctorum qui in collegis philosophiae et medicinae Bononiae laureati fuerunt ab anno 1480 usque ad annum 1800, Milano 1962.

${ }^{67}$ L. A. B irke n m a je r, Mikołaj Wodka, s. 240-245; G. R o s iń s k a, Scientific Writings, s. 48, 105; M. M a r k o w s k i, Astronomia, s. 159-160; A. G ą s i or o w s k i, Kanonicy włocławscy, s. 37.

${ }^{68}$ L. A. B irke n m a j e r, Mikołaj Wodka, s. 231.

${ }_{69}$ Tamże, s. 210-211, 222; A. G ą s i o r o w s k i, Kanonicy włocławscy, s. 38. 
Carboni M., La Gabella Grossa di Bologna. La formazione di una grande azienda fiscale, Il Carrobbio 16, 1990.

De Coster A., Foreign and Citizen Teachers at Bologna University in the 15th and 16th centuries. Statutes, statistics and student teachers, Annali di storia delle università italiane $12,2008$.

Dembiński P., Poznańska kapituła katedralna schyłku wieków średnich. Studium prozopograficzne 1428-1500, Poznań 2012.

Dobrzycki J., Markowski M., Przypkowski T., Historia astronomii w Polsce, t. I, Wrocław 1975.

Gąsiorowski A., Kanonicy włocławscy w najstarszej metryce kapitulnej (1435-1500), w: Duchowieństwo kapitulne w Polsce średniowiecznej i wczesnonowożytnej. Studia nad pochodzeniem i funcjonowaniem elity kościelnej, Toruń 2000.

Isajewicz J., Jerzy z Drohobycza we Włoszech i w Krakowie, Małopolskie Studia Historyczne 6, 1963, nr 3-4.

Knoll P. W., „A Pearl of Powerful Learning”. The University of Cracow in the Fifteenth Century, Leiden-Boston 2016.

Kozłowska A., Polskie prognostyki o komecie z 1472 roku. Analiza zawartości treściowej, Studia Mediewistyczne 29, 1992.

Kristeller P. O., Iter Italicum. Accedunt alia itineraria. A Finding List of Uncatalogued or Incompletely Catalogued Humanistic Manuscripts of the Renaissance in Italian and Other Libraries, t. VI, Leiden-London 1992.

Lachs J., Lekarze krakowskiej kapituły katedralnej, Kraków 1905.

Malagola C., I rettori nell'antico Studio e nella moderna università di Bologna, w: tenże, Monografie storiche sullo Studio Bolognese, Bologna 1888.

Markowski M., Astronomia et astrologia Cracoviensia [!] ante annum 1550, Firenze 1990.

Markowski M., I legami fra la scuola cracoviana di astronomia e l'Università di Bologna nel secolo XV, w: Commentationes historicae, Warszawa-Kraków 1988.

Markowski M., Okresy rozwoju astronomii w Polsce w epoce przedkopernikańskiej, Studia Warmińskie 9, 1972.

Markowski M., Repertorium bio-bibliographicum astronomorum Cracoviensium medii aevi, Studia Mediewistyczne 28, 1992.

Morelli G., De Studio scolarium civitatis Bononie manutenendo. Gli statuti del Comune (13351454) per la tutela dello Studio e delle Università degli scolari, Archiginnasio 76, 1981.

Ożóg K., The Role of Poland in the Intellectual Development of Europe in the Middle Ages, Kraków 2009.

Pessina Longo H., Georgius de Russia, rettore a Bologna nel XV secolo, Bologna 1988.

Piana C., Nuovi documenti sull’Università di Bologna e sul Collegio di Spagna, Bolonia 1976 (Studia Albornotiana, XXVI).

Rosińska G., Scientific Writings and Astronomical Tables in Cracow a Census of Manuscript Sources (XIVth-XVIth Centuries), Wrocław 1984 (Studia Copiernicana XXII).

Rybus H., Królewicz kardynał Fryderyk Jagiellończyk jako biskup krakowski i arcybiskup gnieźnieński, Warszawa 1935.

Simili A., I lettori di medicina e chirurgia nello Studio di Bologna dal 1460 al 1500, Bologna 1941.

Sorbelli A., Gli stipendi dei Professori dell'Università di Bologna nel secolo XIV, L'Archiginnasio 7, 1912.

Sroka S. A., I rettori polacchi dell'universitas scholarium dello Studio bolognese nella seconda metà del XV secolo, Annali di storia delle università italiane 19, 2015, nr 2.

Sroka S. A., Polacy w Bolonii u schyłku średniowiecza w świetle diariusza Gaspare Codibò z lat 1471-1508, w: Memoria viva. Studia historyczne poświęcone pamięci Izabeli Skierskiej (1967-2014), Warszawa-Poznań 2015.

Starzyński M., Zgon i pogrzeb Kazimierza Jagiellończyka (1492), w: Narodziny Rzeczypospolitej. Studia z dziejów średniowiecza i czasów wczesnonowożytnych, Kraków 2012.

Thorndike L., A History of Magic and Experimental Science, t. IV, New York 1934. 


\title{
The salaries of professors from Poland at the University of Bologna in the second half of the 15 th century
}

\begin{abstract}
Summary
In the State Archive of Bologna there are registers of salaries paid to the professors of the University of Bologna, staring from 1470. They were paid quarterly, usually in April, July, October and December. Every register includes the names of all lecturers, who were employed in a given academic year, beginning with the university of law (citramontans and ultramontans), then the medical university and artists, and at the end are those who held various university dignities and offices. Among all professors in the analysed period (from 1470 till the end of the $15^{\text {th }}$ century) there are names of four Poles, who lectured in Bologna at the time and received salaries for that. They were: Jakub of Zalesie, Jan de Bossis, Jerzy Koternak of Lviv and Mikołaj Wódka of Kwidzyn, later excellent astronomers. Jan de Bossis, although he most probably came from the Bossi family of Milan, is listed in Bologna records as Polonus. Besides the registers of salaries, in the archive of Bologna there also survive lists of punishments for not holding the classes. These were financial penalties, diminishing a professor's salary. The paper discusses briefly the lives of the Poles mentioned, with special attention to their stay and activities at the University of Bologna. All of them were counted as members of Polish intellectual elite of the last three decades of the $15^{\text {th }}$ century.
\end{abstract}

